\title{
PELATIHAN PEMBUATAN LAMPU EMERGENCY MENGGUNAKAN LIGHT EMITTING DIODE (LED) BAGI SISWA SMA BUDHI LUHUR PEKANBARU
}

\section{TRAINING OF EMERGENCY LIGHTING LAMPS USING LIGHT EMITTING DIODE (LED) FOR STUDENTS SMA BUDHI LUHUR PEKANBARU}

\author{
${ }^{1)}$ Atmam, ${ }^{2}$ Zulfahri, ${ }^{3)}$ Usaha Situmeang \\ 1,23 Program Studi Teknik Elektro, Fakultas Teknik, Universitas Lancang Kuning \\ Jl. Yos Sudarso km. 8 Rumbai, Pekanbaru, Telp. (0761) 52324 \\ Email: atmam@unilak.ac.id, zulfahri@unilak.ac.id, usahasitumeang@unilak.ac.id
}

\begin{abstract}
ABSTRAK
Sekolah Menengah Atas (SMA) Budhi Luhur Pekanbaru merupakan salah satu sekolah menengah atas swasta yang beralamat di jalan Paus Ujung kelurahan Limbungan Baru kecamatan Rumbai Pesisir Kota Pekanbaru Provinsi Riau. Visi dari SMA Budhi Luhur Pekanbaru adalah berbudi pekerti luhur, beriman dan bertaqwa serta berbudaya melayu dengan salah satu indikator visi berprestasi dibidang akademik dan non akademik. Sarana dan prasarana yang dimiliki SMA Budhi Luhur untuk mendukung proses pembelajaran adalah laboratorium terpadu dan komputer. Permasalahan yang terjadi adalah tingkat pengetahuan dan keterampilan dari siswa SMA Budhi Luhur Pekanbaru terhadap penguasaan ilmu pengetahuan dan teknologi (IPTEK) sangat minim sekali, disebabkan oleh kurangnya kegiatan yang berhubungan dengan IPTEK tersebut. Melihat kondisi tersebut, maka haruslah ada upaya untuk membekali siswa SMA Budhi Luhur Pekanbaru dengan IPTEK. Salah satu pengetahuan dan keterampilan yang berhubungan dengan teknologi untuk mengembangkan potensi yang ada pada siswa SMA Budhi Luhur Pekanbaru adalah melalui pemberian pelatihan membuat rangkaian elektronika sederhana. Pengetahuan dan keterampilan ini berupa pembuatan lampu emergency menggunakan Light Emiting Diode (LED) untuk pencahayaan ruangan pada saat listrik padam dimalam hari. Dari hasil kegiatan pengabdian kepada masyarakat ini, pengetahuan peserta tentang defenisi elektronika, $100 \%$ peserta sudah memahaminya dengan peningkatan sebesar $96 \%$ serta pengetahuan pembagian dan fungsi komponen elektronika dari peserta terjadi peningkatan sebesar 92\%. Peningkatan pengetahuan peserta tentang rangkaian lampu emergency menggunakan LED sebesar $96 \%$ dan untuk pengetahuan teknik penyolderan komponen elektronika sebesar $100 \%$.
\end{abstract}

Kata kunci : Elektronika, Light Emiting Diode (LED)

\begin{abstract}
High School (SMA) Budhi Luhur Pekanbaru is one of the private high school which is located at Paus Ujung street of Limbungan Baru sub-district of Rumbai Pesisir, Pekanbaru City of Riau Province. The vision of SMA Budhi Luhur Pekanbaru is virtuous noble character, faithful and devout and cultured with one of the indicators of achievement in the field of academic and non academic achievement. Facilities and infrastructure owned by SMA Budhi Luhur to support the learning process is an integrated laboratory and computer. Problems that occur is the level of knowledge and skills of high school students Budhi Luhur Pekanbaru to mastery of science and technology (Science and Technology) is very minimal, caused by the lack of activities related to science and technology. Seeing these conditions, then there should be efforts to equip high school students Budhi Luhur Pekanbaru with science and technology. One of the knowledge and skills to develop the existing potential in Budhi Luhur Pekanbaru high school students is through the provision of training to make simple electronics circuit. This knowledge and skill in the form of emergency lighting using Light Emitting Diode (LED) for room lighting during power outages at night. From the results of this community service activity, the participants' knowledge about definition of electronics, $100 \%$ of participants already understand it with $96 \%$ increase as well as knowledge sharing and function of electronic component of the participant there was an increase of 92\%. Enhancement of participant knowledge about emergency lighting circuit using LED equal to $96 \%$ and for knowledge of soldering technique of electronic component $100 \%$.
\end{abstract}

Keywords : Electronics, Light Emitting Diode (LED)

\section{Submited : 2 April 2017 Revision : 23 Juni 2017 Accepted : 10 September 2017}




\section{PENDAHULUAN}

Sekolah Menengah Atas (SMA) Budhi Luhur Pekanbaru merupakan salah satu sekolah menengah atas swasta yang berdiri pada tanggal 16 Desember 1988 yang beralamat di jalan Paus Ujung Kecamatan Rumbai Pesisir, Kota Pekanbaru Provinsi Riau. Visi dari SMA Budhi Luhur Pekanbaru adalah berbudi pekerti luhur, beriman dan bertaqwa serta berbudaya melayu dengan salah satu indikator visi berprestasi dibidang akademik dan non akademik. Adapun status akreditasi yang diperoleh oleh SMA Budhi Luhur Pekanbaru saat ini adalah berakreditasi B. Menurut data profil sekolah SMA Budi Luhur Pekanbaru Tahun 2013/2014, tenaga pengajar dari SMA Budi Luhur berjumlah 23 orang berpendidikan rata-rata Sarjana (S-1) kependidikan. Selanjutnya, sarana dan prasarana yang dimiliki SMA Budhi Luhur untuk mendukung proses pembelajaran adalah laboratorium terpadu dan komputer. Pada tahun 2015, jumlah siswa dari SMA Budi Luhur sebanyak 137 siswa. Sesuai dengan indikator dari SMA Budhi Luhur Pekanbaru berprestasi dibidang akademik dan non akademik, yang berarti siswa harus memiliki pengetahuan dan keterampilan. Persoalan pengetahuan dan keterampilan dari siswa SMA Budhi Luhur Pekanbaru, erat kaitannya dengan kegiatan yang ada di sekolah tersebut. Saat ini tingkat pengetahuan dan keterampilan dari siswa SMA Budhi Luhur terhadap penguasaan ilmu pengetahuan dan teknologi (IPTEK) sangat minim sekali. Hal ini disebabkan oleh kurangnya kegiatan yang berhubungan dengan IPTEK tersebut. Melihat kondisi tersebut, dan juga adanya kondisi lampu padam atau mati lampu pada perumahan, maka haruslah ada upaya untuk membekali siswa SMA Budhi Luhur Pekanbaru dengan IPTEK. Salah satu pengetahuan dan keterampilan yang berhubungan dengan teknologi untuk mengembangkan potensi yang ada pada siswa SMA Budhi Luhur Pekanbaru adalah melalui pemberian pelatihan membuat rangkaian elektronika sederhana. Pengetahuan dan keterampilan ini berupa pembuatan lampu emergency menggunakan Light Emiting Diode
(LED) untuk pencahayaan ruangan pada saat listrik padam dimalam hari.

Lampu adalah alat penerangan yang sangat penting dimana lampu dapat memberikan suatu keindahan pada objek yang disinarinya. Namun, kondisi sumber listrik dari PLN yang tidak $100 \%$ dapat dialirkan terus menerus, membuat sewaktu-waktu kondisi pencahayaan ruangan yang semestinya tidak dapat digunakan. Penerapan sebuah sistem yang dapat dengan otomatis menyalakan sumber pencahayaan alternatif berupa susunan LED akan sangat efektif untuk diterapkan. Hal ini dikarenakan arus yang dibutuhkan untuk menyalakan LED relatif sangat kecil, namun memiliki tingkat pencahayaan yang cukup tinggi (Fithri, 2014).

LED adalah semikonduktor yang dapat mengubah energi listrik lebih banyak menjadi cahaya, merupakan perangkat keras dan padat (solid-state component) sehingga lebih unggul dalam ketahanan (durability). Selama ini LED banyak digunakan pada perangkat elektronik karena ukuran yang kecil, cara pemasangan praktis, serta konsumsi listrik yang rendah. Salah satu kelebihan LED adalah usia relativ panjang, yaitu lebih dari 30.000 jam. Kelemahannya pada harga per lumen (satuan cahaya) lebih mahal dibandingkan dengan lampu jenis pijar, TL dan SL, mudah rusak jika dioperasikan pada suhu lingkungan yang terlalu tinggi, misal di industri (Suhardi, 2014).

Penggunaan LED sebagai sumber cahaya penerangan, karena LED merupakan lampu hemat energi yang memiliki kelebihan dibandingkan dengan lampu konvensional lainnya selain umurnya panjang yaitu 50.000 jam juga lebih hemat dibandingkan dengan lampu pinjar dan lampu swabalast. Selain itu, lampu LED juga ramah lingkungan karena lampu LED tidak mengandung merkuri dan menghasilkan emisi $\mathrm{CO} 2$ yang lebih rendah bila dibandingkan lampu lampu konvesional lainnya (Ade Ramdan, 2013).

Dari hasil kegiatan ini diharapkan menghasilkan siswa yang mempunyai kemampuan dan keterampilan dalam bidang 
teknologi, sehingga kedepannya akan mempermudah siswa dalam melanjutkan kejenjang pendidikan tinggi.

Berdasarkan uraian di atas, bahwa indikator dari SMA Budhi Luhur Pekanbaru adalah berprestasi dibidang akademik dan non akademik yaitu memiliki pengetahuan dan keterampilan. Saat ini tingkat pengetahuan dan keterampilan dari siswa SMA Budhi Luhur Pekanbaru terhadap penguasaan ilmu pengetahuan dan teknologi (IPTEK) sangat minim sekali, disebabkan oleh kurangnya kegiatan yang berhubungan dengan IPTEK tersebut. Melihat kondisi tersebut di atas, maka diperlukan pelatihan bagi siswa SMA Budhi Luhur Pekanbaru untuk meningkatkan kemampuan dibidang IPTEK. Salah satu kegiatannya adalah memberikan pengetahuan dan keterampilan membuat rangkaian elektronika sederhana seperti memberi pencahayaan ruangan pada saat listrik padam dimalam hari. Keterampilan ini berupa pembuatan lampu emergency menggunakan Light Emiting Diode (LED). Dari hasil kegiatan ini diharapkan siswa mempunyai pengetahuan, kemampuan dan keterampilan yang berhubungan dengan IPTEK yaitu membuat lampu emergency menggunakan Light Emiting Diode (LED).

\section{METODE}

Metode pelaksanaan yang digunakan dalam kegiatan ini adalah:

1. Penyuluhan.

Penceramah memberikan teori dasar tentang komponen elektronika, teori lampu emergency menggunakan LED dan teknik merakitnya.

2. Pelatihan

Siswa melakukan praktek secara langsung pembuatan lampu emergency menggunakan LED di dampingi oleh tim pelaksana pengabdian kepada masyarakat.

3. Evaluasi

Teknik mengevaluasi hasil kegiatan adalah dengan memberikan kuisioner kepada peserta yang mencakup seluruh materi sebelum dan sesudah pelatihan.

\section{HASIL DAN PEMBAHASAN}

\section{Hasil}

Kegiatan pengabdian kepada masyarakat ini di ikuti oleh Siswa Sekolah Menengah Atas Budhi Luhur Pekanbaru yang dilaksanakan pada tanggal 27 Maret 2017. Adapun jumlah peserta yang hadir pada kegiatan ini adalah 25 orang dan kuisioner yang diberikan adalah untuk 25 orang. Dari hasil evaluasi pelaksanaan penyuluhan ini melalui Pre-Test dan Post-Test, dapat dikatakan berjalan dengan baik, karena dari peserta yang hadir sebanyak 25 orang menjawab kuisioner yang diberikan. Pada Gambar 1 terlihat peserta menyimak materi yang diberikan oleh tim pengabdian masyarakat tentang pembuatan pembuatan lampu emergency menggunakan LED.

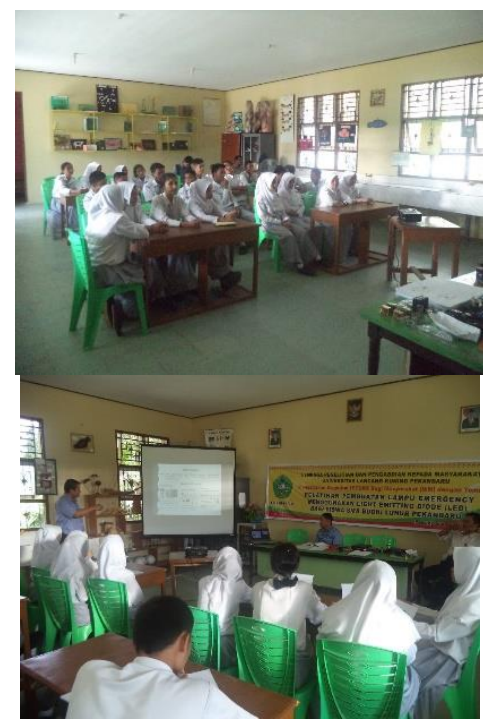

Gambar 1. Peserta pelatihan dan pemberian materi

Kegiatan berikut yang dilakukan oleh peserta adalah melaksanakan praktek secara langsung, yaitu merakit lampu emergency menggunakan LED yang didampingi oleh tim pengabdian kepada masyarakat. Pelaksanaan kegiatan perakitan power supply bagi peserta atau siswa dibagi menjadi beberapa kelompok. Setiap kelompok mendapatkan pengetahuan langsung tentang komponen elektronika dan perakitan lampu emergency menggunakan LED 
serta mengecek hasil dari perakitan yang dilakukannya seperti pada Gambar 2.

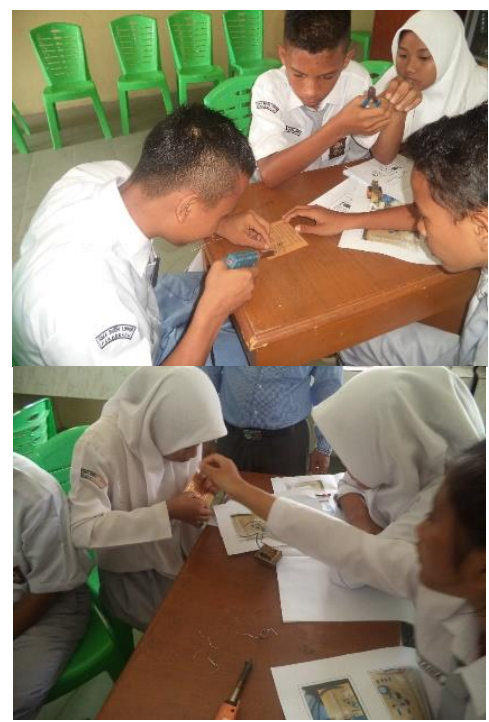

Gambar 2. Peserta melakukan perakitan lampu emergency menggunakan LED

Hasil kuisioner seperti pada tabel 1 dan setelah selesai ceramah dilaksanakan, diadakan

Tabel 1. Hasil Pre-Test dan Post-Test kegiatan

\begin{tabular}{|c|c|c|c|c|c|}
\hline \multirow[t]{2}{*}{ Pertanyaan } & \multicolumn{2}{|c|}{ Pre Test (\%) } & \multicolumn{2}{|c|}{ Post Test (\%) } & \multirow{2}{*}{$\begin{array}{c}\text { Peningkatan } \\
(\%)\end{array}$} \\
\hline & $\mathrm{Ya}$ & Tidak & $\mathrm{Ya}$ & Tidak & \\
\hline $\begin{array}{l}\text { 1. Apakah anda mengetahui tentang defenisi } \\
\text { elektronika? }\end{array}$ & 4 & 96 & 100 & 0 & 96 \\
\hline $\begin{array}{l}\text { 2. Apakah anda mengetahui tentang pembagian dan } \\
\text { fungsi komponen elektronika? }\end{array}$ & 8 & 92 & 100 & 0 & 92 \\
\hline $\begin{array}{l}\text { 3. Apakah anda mengetahui defenisi Ligth Emiting } \\
\text { Diode (LED) ? }\end{array}$ & 4 & 96 & 100 & 0 & 96 \\
\hline $\begin{array}{l}\text { 4. Apakah anda mengetahui rangkaian lampu } \\
\text { emergency menggunakan LED ? }\end{array}$ & 4 & 96 & 96 & 4 & 96 \\
\hline $\begin{array}{l}\text { 5. Apakah anda pernah membuat lampu emergency } \\
\text { menggunakan LED? }\end{array}$ & 0 & 100 & 100 & 0 & 100 \\
\hline $\begin{array}{l}\text { 6. Apakah anda mengetahui teknik penyolderan } \\
\text { komponen elektronika? }\end{array}$ & 0 & 100 & 100 & 0 & 100 \\
\hline $\begin{array}{l}\text { 7. Apakah anda mengetahui pengujian lampu } \\
\text { emergency menggunakan LED? }\end{array}$ & 0 & 100 & 100 & 0 & 100 \\
\hline $\begin{array}{l}\text { 8. Apakah anda puas terhadap pelaksanaan acara } \\
\text { pelatihan ini? }\end{array}$ & - & - & 100 & 0 & 100 \\
\hline
\end{tabular}

\section{Pembahasan}

Hasil Pre-Test yang dilaksanakan sebelum penyuluhan menunjukkan bahwa peserta atau siswa mengetahui tentang elektronika sebanyak 1 orang atau $4 \%$ dan $96 \%$ tidak mengetahui tentang defenisi elektronika. Pengetahuan peserta atau siswa tentang pembagian dan fungsi komponen elektronika sebesar $8 \%$ peserta yang mengetahui dan $92 \%$ tidak mengetahui. Untuk pertanyaan kuisioner :
Apakah anda mengetahui defenisi Ligth Emiting Diode (LED)?, 96\% peserta (24 orang) menjawab tidak mengetahui tentang defenisi Ligth Emiting Diode (LED). Selanjutnya, pertanyaan : "Apakah anda mengetahui rangkaian lampu emergency menggunakan LED ?", 1 peserta menjawab "Ya" dan 24 peserta menjawab "Tidak" sehingga dapat dipresentasikan bahwa $96 \%$ peserta tidak 
mengetahui tentang rangkaian lampu emergency menggunakan LED.

Dari pertanyaan : "Apakah anda pernah membuat lampu emergency menggunakan LED?". Hasil yang diperoleh bahwa seluruh peserta (25 orang) menjawab "Tidak". Secara persentase bahwa $100 \%$ peserta tidak pernah membuat lampu emergency menggunakan LED. Untuk pertanyaan "Apakah anda mengetahui teknik penyolderan komponen elektronika?", dan dari peserta yang mengisi kuisioner, $100 \%$ tidak mengetahuinya. Untuk pertanyaan "Apakah anda mengetahui pengujian lampu emergency menggunakan LED?", semua peserta menjawab tidak (100\%).

Hasil Post Test yang dilaksanakan setelah penyuluhan dan pelatihan menunjukkan bahwa pengetahuan peserta tentang defenisi elektronika sudah menunjukkan perubahan dari tidak mengetahui menjadi memahami (100\%) dan terjadi peningkatan $96 \%$. Pengetahuan tentang pembagian dan fungsi komponen elektronika, juga sudah mengalami peningkatan yaitu $92 \%$ peserta sudah mengetahui dimana awalnya hanya $8 \%$ peserta yang mengetahuinya. Selanjutnya dari pertanyaan tentang "Apakah anda mengetahui defenisi Ligth Emiting Diode (LED) ?" Dari jawaban yang diberikan $100 \%$ sudah mengetahuinya dan terjadi peningkatan sebesar 96\%. Dari pertanyaan tentang "Apakah anda mengetahui rangkaian lampu emergency menggunakan LED", $100 \%$ peserta sudah mengetahuinya dimana awalnya hanya $4 \%$, sehingga terjadi peningkatan sebesar 96\%. Kemudian untuk pertanyaan; "Apakah anda pernah membuat lampu emergency menggunakan LED?” maka setelah dilakukan penyampaian materi penyuluhan, $100 \%$ sudah mengetahuinya dan terjadi peningkatan pengetahuan sebesar $100 \%$.

Untuk pertanyaan "Apakah anda mengetahui teknik penyolderan komponen elektronika?", dari peserta yang mengisi kuisioner, $100 \%$ sudah mengetahuinya dan hanya $4 \%$ yang tidak mengetahui. Untuk pertanyaan "Apakah anda pernah membuat rectifier satu phasa?", dari hasil post-test menjawab "Ya" sebesar $84 \%$ dan $16 \%$ menjawab "Tidak" dengan demikian terjadi peningkatan sebesar $84 \%$. Selanjutnya pertanyaan "Apakah anda mengetahui teknik penyolderan komponen elektronika?" setelah diberikan pelatihan $100 \%$ peserta sudah mengetahuinya. Kemudian untuk pertanyaan "Apakah anda mengetahui pengujian lampu emergency menggunakan LED ?", semua peserta menjawab "Ya" atau semua peserta mengetahuinya (100\%).

Untuk tingkat keberhasilan dan kepuasan dari acara pengabdian masyarakat ini tentang pembuatan lampu emergency menggunakan light emitting diode (LED), $100 \%$ peserta menyatakan puas dengan menjawab "Ya" pada lembar kuisioner posttest.

\section{SIMPULAN}

Pengetahuan peserta tentang defenisi elektronika, $100 \%$ peserta sudah memahaminya dengan peningkatan sebesar $96 \%$ serta pengetahuan pembagian dan fungsi komponen elektronika dari peserta terjadi peningkatan sebesar $92 \%$. Peningkatan pengetahuan peserta tentang rangkaian lampu emergency menggunakan LED sebesar 96\% dan untuk pengetahuan teknik penyolderan komponen elektronika sebesar $100 \%$.

\section{DAFTAR PUSTAKA}

Ade Ramdan, Dicky Rianto Prajitno, Herlan, E. A. G. (2013). LED-based Smart Lamp with Multi Sensor Lampu Pintar Berbasis LED dengan Multi Sensor. Jurnal INKOM, 7 (November), 67-73.

Fithri, N. (2014). Pengembangan Emergency Lamp Dengan LED Luxeon Menggunakan Metode Quality Function Deployment (QED). Seminar Nasional Sains dan Teknologi 2014 Fakultas Teknik Universitas Muhammadiyah Jakarta (pp. 1-7).

Suhardi, D. (2014). Prototipe Controller Lampu Penerangan LED (Light Emitting Diode) Independent Bertenaga Surya. Jurnal Gamma, 10 (September), 116-122 